\title{
Família Pós-Divórcio: A Visão dos Filhos
}

\author{
Family after divorce: Children's view
}

Leila Maria

Torraca de Brito

Universidade

do Estado do

Rio de Janeiro pesquisa. 


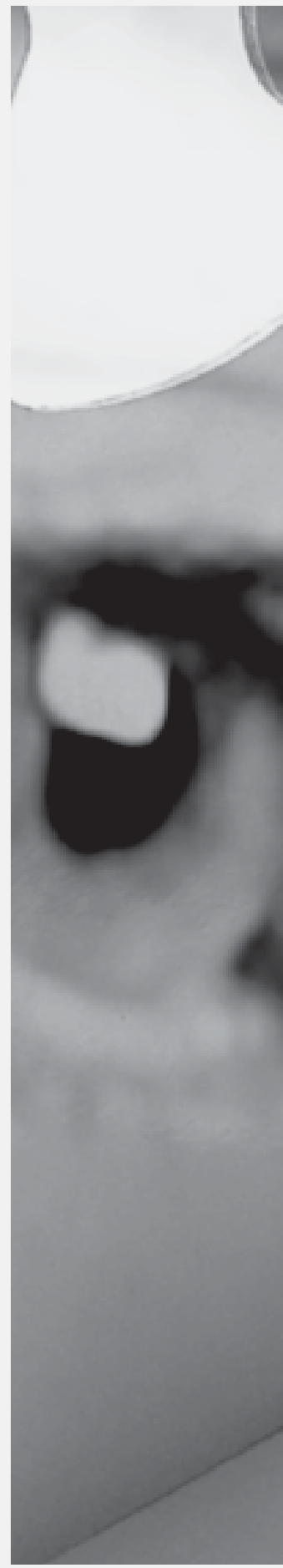

Resumo: O artigo apresenta resultados de pesquisa qualitativa realizada com jovens adultos - filhos de pais separados -, quando se procurou analisar como percebem as mudanças que ocorreram em suas vidas em decorrência do rompimento conjugal dos pais, especialmente em relação à convivência familiar. Com esse objetivo, foram realizadas 30 entrevistas individuais com pessoas das camadas médias da população, residentes no Rio de Janeiro, na faixa etária de 21 a 29 anos, filhos de pais separados. Esperada por alguns entrevistados, inexplicável para outros, a separação dos pais trouxe desdobramentos vistos como desagradáveis por alguns filhos. Dentre essas repercussões, destaca-se o fato de serem colocados no centro das desavenças, o afastamento do pai que saiu de casa, a preocupação com o genitor com quem ficaram residindo e a dificuldade para aceitar novos relacionamentos dos pais. Pela impossibilidade de se generalizar as consequiências do divórcio para os membros da família, conclui-se que é de grande importância a avaliação dos desdobramentos da separação conjugal de forma diferenciada no que diz respeito aos pais e aos filhos.

Palavras-chave: parentalidade, separação conjugal, divórcio, Psicologia jurídica.

Abstract:This paper presents qualitative research done with young adults, children of divorced parents, to whom questions were asked, in a general sense, on how they had felt the changes in their personal lives after the separation. Efforts were made to interview thirty middle class individuals resident in Rio de Janeiro, from 21 to 29 years old, all children of divorced parents. Parental separation was expected by some and unexpected by others, but for most it brought unpleasant consequences. Facts within these results are emphasized, such as: they were put in the middle of the dissension, the lack of fatherhood, further care by whom they had started living with and difficulties to deal with their parent's new friends or relationships. It has been concluded that it is impossible to generalize the consequences of marital separation or divorce to all former family members, but it is necessary to perfectly distinguish, in further studies, parents from children.

Key words: parentalhood, marital separation, divorce, Forensic Psychology. 
"os efeitos do divórcio na vida dos filhos serão sempre de difícil avaliação, porque não sabemos o que teria acontecido se os pais estivessem juntos"

Giddens
1 No presente trabalho, divórcio e separação conjugal não serão diferenciados.
Para muitos autores, criamos, com o crescente número de divórcios ${ }^{1}$, uma sociedade com novas peculiaridades. No entanto, o aumento acelerado das taxas de separação conjugal em diversos países contrasta com o reduzido número de pesquisas qualitativas sobre a temática. Como cita Souza (2003): “o divórcio é assunto particularmente explorado em publicações norte-americanas, e nelas predominam, ainda, os estudos quantitativos" (p.204). Wallerstein e Kelly (1998, p.15), pesquisadoras com vasta experiência no tema, acreditam que ainda se dispõe de um número “perigosamente baixo” de investigações sobre o divórcio, especialmente no que diz respeito à visão dos filhos sobre tal acontecimento.

No Brasil, revistas de circulação nacional vêm estampando, com freqüência, matérias que abordam a adequação ou o acerto daqueles que resolvem se separar, com base no argumento de que, quando os pais se sentem mais felizes após a separação, os filhos também o serão, pois não ficariam expostos a conflitos constantes entre os genitores (Mendonça, 2005). Estudos recentes (Wallerstein, Lewis e Blakeslee, 2002) apontam, entretanto, que esta pode não ser a realidade em muitos casos, na medida em que o rompimento conjugal acarreta experiências distintas para pais e filhos, com desdobramentos que não devem ser analisados de forma unificada. Para as autoras citadas, que realizaram, nos Estados Unidos, vasto estudo longitudinal com filhos de pais separados, acompanhando-os até a fase adulta, a compreensão de que haveria uma “felicidade expansiva”, como conceituam (p.25), seria um dos "mitos acalentados" a respeito do divórcio. Por meio das pesquisas que empreenderam, observaram que, com a separação dos pais, dificuldades de nova ordem podem surgir para os filhos, com repercussões a longo prazo. Perceberam, ainda, que, quando se unificam as conseqüências, “os filhos não são considerados separadamente de seus pais. Suas necessidades e até seus pensamentos são incorporados aos planos do adulto” (p.25).

Outro item constantemente apontado em matérias que abordam o tema do divórcio é o expressivo número de filhos de pais separados na sociedade contemporânea, fato que ajudaria aos que precisam passar por esse processo a naturalizar o ocorrido com seus pais. Quanto a esse aspecto, observou-se também que, enquanto alguns autores como Wagner, Falcke e Meza (1997) explicam que “as conseqüências do divórcio nos filhos estão diminuindo à medida que este está se tornando, a cada dia, mais comum e aceitável” (p.156), outros, como Giddens (1999), compreendem que o aumento do número de famílias divorciadas pode não apresentar uma correlação direta com os fatos que atingem os filhos. Reconhece o autor que "os efeitos do divórcio na vida dos filhos serão sempre de difícil avaliação, porque não sabemos o que teria acontecido se os pais estivessem juntos" (p.102). Preocupa-se Giddens, sobretudo, com as “estratégias políticas" (p.103) que se deveriam implantar para apoiar as diferentes configurações familiares contemporâneas na manutenção do cuidado de suas crianças.

De forma semelhante, Hurstel (1999), no estudo de temas relacionados à parentalidade, sugere que se deve prestar atenção ao entrelaçamento do singular e do social, sustentando que o contexto social pode apoiar ou fragilizar o exercício da paternidade/ maternidade.

Seguindo esse viés teórico e dando seqüência a investigações científicas desenvolvidas sobre o exercício da parentalidade após a separação conjugal, voltou-se o foco de pesquisa para filhos de pais separados, buscando compreender a visão destes, ao ingressarem na fase adulta, sobre a separação conjugal de seus responsáveis. Na investigação em pauta, procurou-se entender como os filhos avaliavam as mudanças que ocorreram em suas vidas após 
a separação dos pais, especialmente no que diz respeito ao relacionamento entre pais e filhos. Será que, quando adultos, retratam a separação dos pais foi uma solução adequada às suas necessidades? Há queixas em relação ao contexto familiar pós-divórcio? Como conceituam o relacionamento estabelecido com o pai e com a mãe?

\section{Método}

$\mathrm{Na}$ pesquisa realizada, optou-se pelo uso de metodologia qualitativa, partindo-se do entendimento de que essa abordagem poderia oferecer melhores recursos à investigação. Na coleta de dados empreendida com jovens adultos, filhos de pais separados, foram realizadas entrevistas individuais, semiestruturadas. Os temas abordados no roteiro de perguntas incluíam o momento da separação, a definição dos pais sobre a guarda dos filhos, o relacionamento e o convívio dos entrevistados com o pai com a mãe e com a família extensa após a separação, o relacionamento atual com os pais, a visão sobre a separação dos pais e as mudanças almejadas no contexto familiar.

A amostra da pesquisa foi composta por 30 sujeitos (S) - 14 homens e 16 mulheres - de classe média, na faixa etária de 21 a 29 anos, que residiam no Rio de Janeiro e se declaravam filhos de pais separados. Assim, constaram da amostra tanto filhos cujos pais eram separados legalmente como aqueles que ainda os tinham "casados no papel”, como explicaram os entrevistados. Havia também exemplos de pais que não foram casados, mas viveram em união estável. Os que concederam entrevistas ${ }^{2}$ foram indicados por conhecidos dos membros da equipe de pesquisa que, inicialmente, sondavam sobre a disponibilidade do sujeito em participar voluntariamente da investigação. Caso a resposta fosse positiva, era feito um contato inicial por telefone ou pessoalmente, visando a maiores esclarecimentos sobre o trabalho e a possibilidade de serem agendados dia, hora e local para a realização da entrevista. Os encontros para a coleta de dados tiveram duração média de 40 minutos, em local escolhido pelos próprios entrevistados, entendendo-se que estes deveriam sugerir um ambiente onde se sentissem à vontade para falar sobre o tema.

Cumprindo orientações éticas, foi solicitado a todos os entrevistados que assinassem o termo de consentimento livre e esclarecido, elaborado com vistas ao esclarecimento dos participantes da pesquisa. O material obtido a partir das entrevistas foi avaliado de forma qualitativa, com base na análise de conteúdo (Bardin, 1977), quando os temas abordados foram decompostos em categorias a serem examinadas.

\section{Resultados e discussão}

Cabe observar que muitas questões aqui apontadas não devem ser compreendidas como conseqüência direta do desenlace conjugal. Seguindo a visão de Hurstel (1999), percebe-se a conjunção de uma série de fatores que interferem no contexto familiar, como o comportamento dos responsáveis após a separação, o manejo destes em relação às situações que se estabelecem, as expectativas sociais e as disposições legais referentes à guarda dos filhos.

Dessa maneira, como primeiro ponto, cabe destacar que, se hoje nos referimos à idéia de família no plural, visão semelhante deve acompanhar a estrutura familiar após o rompimento conjugal, na medida em que se percebe a constituição de distintas configurações, reafirmando que não há um padrão de relacionamento após a separação conjugal. Pela descrição dos entrevistados, foi possível listar casais que continuavam a residir na mesma casa dormindo em cômodos separados e, praticamente, sem qualquer comunicação verbal. Havia também aqueles
2 No artigo em questão, identificados por números. 
A sensação que passavam era a de que, como nos contos infantis, algo desaparecera misteriosamente ao toque de uma varinha mágica, só que, agora, falavam do pai que saíra de casa e não de bruxas ou fadas. em que um dos cônjuges mudava de domicílio, alguns mantendo um bom relacionamento, inclusive com visitações periódicas, e outros que não tinham contato há anos.

\section{O momento da ruptura}

Ao descrever o contexto da separação, alguns integrantes do grupo cujos pais se separaram quando os filhos ainda eram pequenos ou bebês revelaram que, na verdade, não se lembravam de qualquer sentimento relacionado ao momento do rompimento conjugal dos pais, não possuindo recordações de residência comum. Em sua memória, constavam apenas as vivências da família pósdivórcio. "Não tenho lembrança do meu pai em casa, tenho algumas fotos, mas não me lembro de nada", disse uma moça de 25 anos (S. 25). Acrescentaram, ainda, saber apenas um lado da história que motivou a separação, ou seja, a versão contada por aquele que permaneceu com a guarda.

Houve os que consideraram o momento da separação como traumático quando, assustados, levaram "um choque" com a notícia, apesar de a revelação ter acontecido quando alguns já eram adolescentes ou adultos. Como não presenciavam relações conflituosas entre os pais - que justificassem o rompimento -, se surpreenderam. "Foi do nada, de repente”, revelou um entrevistado de 24 anos, cujos pais se separaram quando ele contava 17 (S. 7).

Já outro jovem que presenciou a separação dos pais ainda aos 10 anos revelou: "Achava que nada separava meu pai e minha mãe. Aquela coisa de achar que nunca vai acontecer com você” (S. 9). A sensação que passavam era a de que, como nos contos infantis, algo desaparecera misteriosamente ao toque de uma varinha mágica, só que, agora, falavam do pai que saíra de casa e não de bruxas ou fadas.

Notou-se, por meio de tais relatos, que brigas sérias, na frente dos filhos, expondo-os a situações de tensão, nem sempre ocorrem no contexto da separação conjugal. De forma semelhante, na pesquisa desenvolvida por Wallerstein, Lewis e Blakeslee (2002), “a maioria dos filhos do divórcio diz que não fazia idéia de que o casamento dos pais estivesse à beira do abismo” (p.66). Quanto a esse tópico, Souza (2003) também observou que, por vezes, os filhos não percebem a tensão que existe entre os pais antes da separação, sendo a saída de casa de um dos pais interpretada por alguns de seus entrevistados como fonte de muito sofrimento. Dentre os jovens entrevistados para este trabalho, alguns relataram, ainda, o aparecimento de sintomas somáticos após o término da conjugalidade dos genitores.

Avaliando o momento da separação, foi observado que grande parte dos entrevistados não recebeu esclarecimentos sobre o ocorrido. Emprega-se aqui esclarecer no sentido de conversar sobre o assunto com os filhos, deixar que estes façam perguntas e respondê-las, o que difere de um simples comunicado que era dado, às vezes, quando da saída de casa de um dos pais, ou dias após o fato transcorrido. Uma das entrevistadas, hoje com 27 anos (S.4), exemplifica a ausência de explicações quando narra que, aos cinco anos de idade, viu o pai arrumando os pertences e perguntou para onde ele iria. $\mathrm{O}$ pai respondeu que estava indo viajar.

Muitos percebiam que não havia disponibilidade dos pais para abordar o assunto, mesmo anos após a separação.

\section{Considerações sobre a separação}

Inicialmente, apesar de os entrevistados discorrerem sobre o divórcio como um tema natural, comum a muitas famílias atualmente, quando abordavam a separação conjugal dos pais e começavam a falar de suas recordações 
e vivências, esta se tornava um assunto delicado. Alguns, inclusive, se surpreendiam por estar descortinando suas histórias e pelo conteúdo de suas respostas. Encontrou-se, assim, na pesquisa, os que consideraram correta a decisão dos pais de se separar devido às brigas que existiam entre eles. "Eles brigavam muito, a notícia da separação foi boa”, admitiu uma moça de 22 anos, cujos pais se separaram quando ela estava com oito (S. 27). Outros, apesar de não gostarem dos sérios desentendimentos que presenciavam, indicaram que não sentiram tanto a separação, mas foram afetados pelos desdobramentos desta. Narraram situações difíceis pelas quais passaram, sentindo-se desprotegidos, como a jovem que, mesmo menor de idade na época da separação, passou a residir sozinha. Fato parecido ocorreu com outra entrevistada que, também na menoridade, ficou morando com as irmãs, pois não gostavam do padrasto. "Nunca nos demos bem com o meu padrasto, brigávamos muito, e, um dia, ele saiu de casa... Minha mãe foi morar com ele. Não ter a mãe para dar um beijo de manhã deixou a gente mais carente” (S. 28).

No entanto, maior representatividade foi a dos que ainda lastimavam a separação do casal, como o rapaz, de 24 anos, cujos pais estavam separados há sete, e que, enfurecido, afirmou: "Nunca vou gostar" (S.7), acrescentando ainda que, se fosse possível, gostaria de sugerir aos pais “para apagar e fingir que nada aconteceu”. $\mathrm{Na}$ visão de outro rapaz, de 22 anos, com pais separados há 14: “Os filhos sofrem muito com o divórcio, são muito penalizados” (S.1). Acreditavam, esses filhos, que os momentos felizes que viveram enquanto os pais estavam casados marcaram mais, revelando que, pela sua ótica, não se importavam tanto com as brigas ou que estas não eram tão freqüentes ou, ainda, que não presenciavam desentendimentos. Muitos disseram sentir falta de quando os pais estavam casados, ocasião em que desfrutavam de um relacionamento constante com ambos. “O ideal é ter a pessoa dentro de casa. Se não está em casa, não é suficiente [o relacionamento]" (S. 29). Nesse item, pode-se recordar o trabalho de Wallerstein, Lewis e Blakeslee (2002), quando as autoras destacam que, em casamentos nos quais os adultos estão infelizes, os filhos podem estar contentes. De forma semelhante, Fauchier e Margolin (2004) chamam atenção para o fato de que nem sempre o conflito entre os pais implica não haver relações positivas entre estes e os filhos.

Outros entrevistados deixaram claro que aprenderam a conviver no novo contexto familiar. "Na verdade, desde criança eu me forcei a botar na cabeça que isso era o melhor para eles. Sempre tive um pensamento moldado nesse sentido. Depois da terapia, eu vi que não foi tão tranqüilo assim; na verdade, eu sempre quis eles juntos, analisando, com o tempo, vejo que sempre quis eles juntos. Hoje vejo que foi o melhor", descreveu uma moça de 23 anos (S. 17). Nesse grupo, incluíam-se também os que explicaram a necessidade de "encarar" a situação, como relatou o rapaz de 24 anos que, aos 10, presenciou a separação dos pais (S. 8).

Outros participantes da pesquisa, contudo, possuíam pleno discernimento sobre o sentido de suas queixas, chegando a afirmar, como a moça de 26 anos, que "a conduta é totalmente desvirtuada, o divórcio, em si, não” (S. 18). "Já naquela época, não tinha raiva do divórcio, e sim, da distância [do pai]”, disse o rapaz de 22 anos (S. 22).

No questionário respondido por mais de 170 jovens franceses de 15 a 17 anos, publicado como matéria no Le Nouvel Observateur (2003), foi observado que os adolescentes participantes daquele levantamento não aceitavam com facilidade o divórcio dos pais, apesar de esse fato ter sido incorporado como habitual na denominada cultura do divórcio. Em suas respostas, muitos franceses se referiram, também, à vontade de viver com o pai e a mãe juntos, assim como ao choque e
"Nunca vou gostar" (S. T), acrescentando ainda que, se fosse possível, gostaria de sugerir aos pais "para apagar e fingir que nada aconteceu". 
às imagens, que não haviam esquecido, do momento da separação dos pais (p.45). Alguns chegaram a mencionar que esse foi o pior momento de suas vidas.

Souza (2003) aponta dado divergente colhido entre adolescentes. Ao realizar pesquisa, na qual entrevistou 15 jovens na faixa etária de 14 a 18 anos, filhos de pais separados, a autora concluiu que “Apesar de relatar solidão, isolamento e ausência ou incapacidade de encontrar pontos de apoio, todos afirmaram que o divórcio foi uma boa solução para a família” (p.203).

\section{Brigas e recados}

O mal-estar dos filhos no contexto pósseparação também foi exposto por aqueles entrevistados que se sentiram como joguetes entre os pais. "Fala para o seu pai isso, fala para a sua mãe isso, e eu e o meu irmão na berlinda, no meio”, expõe, com tristeza, um rapaz de 23 anos (S. 23).

Outros, como a moça de 25 anos, lembraramse de irmãos que ficaram nessa condição: “Meu pai acampava na porta do prédio e ficava gritando para a minha irmã falar para a minha mãe deixar ele voltar. Imagina a cabeça dela” (S. 25). "O que é ruim é que eles sempre nos envolveram nisso, sempre jogaram a gente na fogueira mesmo! Diversas confusões, e a gente sempre participou de tudo. Acho que podiam ter feito menos estragos”, queixa-se a jovem de 23 anos, ao se referir às brigas entre os pais após o rompimento da relação e entre esses e os novos companheiros. Na visão dessa entrevistada, “não deve ser difícil preservar os filhos dessas confusões, não deve ser tão complicado” (S.13).

Se, ao abordar o momento da ruptura, alguns deixaram claro que não é sempre que os filhos presenciam sérias brigas entre os genitores quando estes ainda estão casados, no item em pauta, desfaz-se também a idéia de que o rompimento conjugal irá, necessariamente, extinguir brigas e desentendimentos entre excônjuges, contribuindo para que os filhos não fiquem expostos a tais desavenças.

Wallerstein, Lewis e Blakeslee (2002) também encontraram, em sua pesquisa, diversos filhos que sofreram muito com as brigas pós-divórcio, seja porque os pais - mesmo não residindo no mesmo domicílio - continuavam travando verdadeiras batalhas, seja porque os desentendimentos se estendiam aos novos relacionamentos dos genitores. Neste último caso, pode-se citar como exemplo o depoimento de uma moça de 21 anos que, na pesquisa empreendida, expressou: "Meus pais nunca brigaram e agora tenho que ficar no meio da briga desses dois” (S. 15), referindose ao pai e à namorada deste.

Alguns entrevistados se queixaram de que os pais, ao desqualificarem o ex-cônjuge, comparavam os defeitos ou dificuldades dos filhos ao comportamento do outro genitor. Segundo uma entrevistada, de 27 anos, foi preciso ter mais idade para poder perceber o que estavam fazendo e questionar os pais se "tudo que não presta (nela) é lixo genético do outro" (S. 4).

Como se evidencia, com a mudança que se estabelece na configuração familiar após a ruptura conjugal, os filhos podem ser colocados no centro das discórdias. Segundo uma moça entrevistada, os pais afirmavam que não se separavam oficialmente por causa dela, motivo pelo qual, apesar de todos saberem que o casamento havia terminado, optaram por permanecer residindo no mesmo apartamento. No entanto, não se falavam dentro de casa e um vivia culpando o outro pelo que acontecia de errado no lar. Nesse contexto, dizia a moça de 23 anos: “(...) me via como culpada disso, me sentia o centro do caos” (S. 11), sendo que sua vontade era a de sair de casa o mais breve possível. Situação semelhante ocorria com o rapaz, também de 
23 anos, com genitores separados há aproximadamente sete anos, mas que residiam no mesmo apartamento por causa dos filhos. Reconhecia o entrevistado que "do jeito que está, é melhor meu pai sair, o clima está estranho” (S. 23), acrescentando depois: “acho que seria a decisão ideal, mas que a gente não perdesse o relacionamento com ele.”

\section{A convivência com os pais após a separação}

De acordo com as estatísticas nacionais, foi grande o percentual dos entrevistados que permaneceu residindo com a mãe após o rompimento conjugal (83,3\%). Alguns ressaltaram, inclusive, que a rotina não sofreu alteração, pois continuaram a morar na mesma casa. Destacaram, em uníssono, o afastamento do pai como a maior conseqüência da separação, afastamento do qual se ressentiam constantemente, devido ao aspecto emocional, e, por vezes, físico. “A gente se via esporadicamente por uns 10 ou 15 minutinhos. Um contato muito superficial mesmo. Numa questão de acompanhamento e presença, foi muito insignificante. Classificaria como ruim”, disse uma moça de 28 anos, com pais separados há 17 anos (S. 5).

Reconheciam que, após o desenlace conjugal dos pais, houve acentuado distanciamento daquele que não permaneceu com a guarda, com sérias repercussões na convivência familiar. “Só passava lá fim de semana, mas era legal, sentia falta, então quando estava com ele, ficava bem”, explicou o rapaz de 22 anos (S. 22) ou, ainda, como afirmou, conformado, o rapaz de 24 anos: "Poderia ser pior. Está ruim, mas está bom... Satisfatório, não é” (S.7). Insistiam que, mesmo com um relacionamento que classificavam como bom, em alguns momentos, sentiam falta de uma convivência mais estreita com o pai. "Fica uma lacuna”, definiu um rapaz de 25 anos que, compreensivo com a separação dos pais, explicou sua observação: "Por exemplo, conversar com o pai no momento do ingresso profissional, conversar sobre futebol, nessas situações que se precisa ter o pai perto para orientar e também se divertir” (S. 30).

Atualmente, na fase adulta, alguns tinham consciência de que o afastamento ocorreu por conta das desavenças entre os pais, mostrando o quanto a conjugalidade e a parentalidade, em certos casos, seguem unificadas mesmo após a separação. Com essa compreensão, alguns atribuíram o não cumprimento da visitação pelo pai aos atritos que comumente surgiam com a ex-mulher e aos arranjos de guarda. "Se não é o pai que está com a guarda, ele deixa de ir, é a lei do menor esforço, no menor atrito, já desiste”, classificou uma moça de 26 anos, com pais separados há 24 anos (S. 18).

Para muitos entrevistados, a saída do pai de casa implicou, também, o distanciamento da família paterna, quando reconheciam que as reuniões com esse núcleo da família não faziam mais parte do cotidiano. "Houve afastamento da parte paterna, acho que é normal perder o contato” (S. 22).

"Não tenho relação com a família do meu pai, tive quando era bem mais nova", reconhece a moça de 28 anos (S. 21). Ou, ainda, da entrevistada que, ao falar sobre o convívio com a família paterna, resumiu: "Me sinto um peixe fora d’água. Não me sinto em família como antes” (S. 5).

Em alguns casos, porém, nota-se que as mães mantinham contato, mesmo que esporádico, com a família do ex-marido, mas seus filhos, não. "Sabia da minha avó paterna pela minha mãe” (S. 22).

Enfáticas em suas conclusões, Wallerstein, Lewis e Blakeslee (2002) expõem que "a perda de continuidade com a história familiar é uma seqüela do divórcio que temos ignorado” (p.61)

Nos depoimentos colhidos, alguns entrevistados já relacionavam o distanciamento paterno ao afastamento que seus filhos
Para muitos entrevistados, a saída do pai de casa implicou, também, o distanciamento da família paterna, quando reconheciam que as reuniões com esse núcleo da família não faziam mais parte do cotidiano. "Houve afastamento da parte paterna, acho que é normal perder o contato"(S. 22). 
provavelmente terão do avô. Lamentavam pelo fato de que seus rebentos não iriam dispor de um avô presente. "Fico preocupado com os meus filhos e sobrinhos, porque não vão ter a figura de um avô”, expôs o rapaz de 25 anos, cujos pais se separaram quando ele estava com três anos (S. 16).

Alterações no relacionamento e nos períodos de convivência com aquele genitor que permaneceu com a guarda - geralmente as mães - também foram relatadas. Com dificuldades para manter os filhos, o guardião, por vezes, se afastava do lar por longos períodos durante o dia devido ao aumento da carga horária de trabalho. "Sempre tive babá, às vezes ficava com a minha avó, teve época de a minha mãe trabalhar manhã, tarde e noite”, conta uma moça de 23 anos (S.17). “(...) minha mãe começou a trabalhar muito, trabalhava 10 horas por dia”, lembra outra, também de 23 anos (S. 19).

Os entrevistados que apresentaram menos queixas quanto à separação conjugal dos pais e a posterior convivência com estes foram aqueles que se sentiram verdadeiramente acolhidos nas duas casas após separação, com livre acesso a ambos os pais. Como mencionou uma entrevistada de 21 anos, com pais separados há 13 anos: "Nunca teve isso de ter que ir de 15 em 15 dias, ou não poder ir porque é dia do meu pai ou da minha mãe. Eu ia sempre quando eu queria” (S. 15). O entendimento de que possuíam duas casas parecia importante para o sentimento de que pertenciam tanto ao mundo de seu pai quanto ao de sua mãe. "Eu sempre tive meu pai e sempre tive minha mãe”(S. 10), revela com firmeza o entrevistado de 26 anos ao explicar que manteve um ótimo contato com os pais após a separação, até porque os dois continuaram a ter muito respeito entre eles.

Nesse acordo, semelhante a uma guarda conjunta, desde o início da separação, parecia haver convicção dos pais de que os filhos deveriam continuar, verdadeiramente, a conviver com ambos. Acolhidos por pai e mãe, continuavam a se sentir como o centro de interesse destes, seguindo a proposta dessa modalidade de guarda (Brito, 2005). "Para mim, o normal é minha mãe poder vir aqui quando quiser e meu pai ir lá quando quiser” (S. 15), revela a moça que residia com o pai, mas possuía livre acesso à casa da mãe. Esclareceu ainda: “(...) tenho meu quarto na casa da minha mãe, meu computador, minha TV, toda a mesma infra-estrutura”. Para esse convívio com ambos os pais, recebeu apoio de familiares. "Minha avó falou que quem se separou dela foi ele, eu não”.

Indicavam, dessa forma, o quanto esse apoio no momento da separação pode funcionar como um valioso suporte para que os vínculos estabelecidos não se esgarcem. Compreendiam também a separação como um fato natural, atribuído a motivos dos pais, talvez porque não tenham sentido sérias conseqüências em suas vidas. "Acho que, em algum momento, me contaram o motivo da separação, mas nunca achei que fosse importante, nunca marcou”, revelou o rapaz de 21 anos, com pais separados há 15 anos (S. 24).

Ao enfocar a guarda conjunta, Poussin e Lamy (2005) reconhecem que é preciso certo esforço inicial dos pais para a adaptação da criança aos dois lares, sendo necessário e adequado respeitar o vínculo da criança com as duas famílias.

Situação totalmente distinta foi encontrada entre os que alternavam a casa onde residiam devido à impossibilidade de continuar morando com um dos pais, quando, sem rumo, migravam de um canto para outro. Nesses casos, passavam tempos na casa do pai e tempos na casa da mãe porque brigavam com um dos genitores ou porque se sentiam alijados do ambiente onde estavam, vendo-se desgarrados, sem raízes, ou como sobras de um relacionamento desfeito. 


\section{As alianças com o guardião}

Ainda no que abrange o convívio com os pais, Gonzalez, Cabarga e Valverde (1994) observaram que, em situações de separação conjugal com litígio, os filhos podem estabelecer alianças com um dos genitores, desenvolvendo uma forte vinculação preferencialmente com o guardião, a quem percebem de maneira mais positiva independentemente do sexo deste. $\mathrm{Na}$ pesquisa empreendida, essa polarização foi encontrada, com mais freqüência, entre as mães e os filhos caçulas, comportamento que tinha início quando a criança mais nova era bem pequena no momento da saída do pai de casa. Nesses casos, o vínculo entre mãe e filho se estreitava, com a genitora jogando toda a sua afetividade para o pequenino, a quem, pela idade, só era permitido visitas esparsas ao pai. Ao longo do desenvolvimento, muito apegada à mãe, a própria criança não conseguia se afastar para visitar o pai, iniciandose uma série de justificativas que, prontamente, eram defendidas pela mãe. Uma das entrevistadas, cujos pais se separaram quando ela nasceu, disse, por exemplo, que possuía um ótimo relacionamento com a mãe, sentindo que o mesmo não ocorria com o pai, de quem se sentia um pouco afastada; quanto à causa, pensativa, questionou: "Não sei se é porque direcionei tudo para a minha mãe ou a distância física”, admitindo posteriormente: "eu sempre me posicionei ao lado de minha mãe, sempre, é incrível” (S. 25).

Visão semelhante foi colhida no relato do rapaz de 25 anos que, ao se referir ao término do casamento dos pais, afirmou: "Eu não sofri, meu irmão sofreu pra caramba, porque ele era mais velho, já entendia e precisava de uma figura paterna, eu não precisava tanto” (S. 16). As alianças estabelecidas entre pais e filhos devem ser percebidas por profissionais que atuam junto aos casos como, por exemplo, nas Varas de Família. Nessas circunstâncias, destaca-se o equívoco que pode existir quando se resolve averiguar com qual dos genitores a criança deseja residir. Aprisionado em um forte vínculo com o guardião, o filho não possui escolha, espelhando a única resposta que lhe é possível, dada a intensidade da situação a que está exposto.

\section{Filhos cuidadores}

Notou-se, também, que alguns filhos passaram a se preocupar mais com o pai que permaneceu com a guarda, tornando-se quase responsáveis por este, em uma clara inversão de papéis. Tais situações ocorriam, com mais freqüência, com mães guardiães que eram dependentes dos próprios pais mesmo na fase adulta, dependência que, mais tarde, se estendia ao marido. Depois, sem alguém para mediar a relação com os filhos, tornaram-se cria dos rebentos. Assim, compartilhavam preocupações e ansiedades preferencialmente com os filhos, sendo emocionalmente dependentes destes, que passavam ao lugar de conselheiros e provedores de cuidado. Como explica uma moça de 24 anos, ao descrever o relacionamento que mantinha com a mãe, de quem era confidente, pois a mãe não possuía amigas: "por vezes, ela [a mãe] perde a autoridade, e eu [a jovem] perco a mãe” (S. 2), ou, ainda, como contou outra participante da pesquisa, de 26 anos, ao narrar que se preocupava muito com a mãe devido ao fato de residir sozinha com esta, justificando: "Sou mais exigente com ela, mais mandona, quando ela faz besteira, eu brigo logo, mas isso não acontece comigo porque sou muito responsável, ela não pode falar nada” (S. 18). Esse dado, de forma ilusória, pode conduzir a uma interpretação generalizada de maior maturidade dos filhos de pais separados, os quais, muito cedo, podem ter deixado as brincadeiras infantis para participar de decisões e discussões adultas por conta das mudanças operadas na estrutura familiar, quando maiores responsabilidades foram depositadas em seus ombros.
Notou-se também, que alguns filhos passaram a se preocupar mais com o pai que permaneceu com a guarda tornando-se quase responsóveis por este, em uma clara inversão de papéis. Tais situações ocorriam, com mais freqüência, com mães guardiães que eram dependentes dos próprios pais mesmo na fase adulta, dependência que, mais tarde, se estendia ao marido. 


\section{Os novos relacionamentos dos pais}

Foi constatada grande dificuldade de os filhos aceitarem o divórcio no seu significado amplo, isto é, um descasamento que possibilita novas uniões conjugais legalizadas, casamentos ou relacionamentos dos pais. $\mathrm{Na}$ escuta dos entrevistados, percebeu-se que alguns compreendiam a separação, mas, em relação aos novos relacionamentos de seus responsáveis, havia muita resistência. Houve queixas de que não se sentiam "em família" quando, nas visitas ao pai, se deparavam com a companheira deste e um lar refeito. "Ficávamos eu, meu irmão, ele... A mulher dele estava lá, mas estou falando de família”, disse o rapaz de 22 anos (S. 22). Outros, com veemência, declararam que sentiam falta do núcleo familiar e do cotidiano, atribuindo aos novos relacionamentos dos pais o rompimento da convivência familiar e o afastamento dos filhos "Era a minha família, e eu vi a minha família desmoronar”, queixa-se uma moça de 24 anos, acrescentando "ela [a companheira do pai] faz a cabeça dele” (S. 6).

Na visão da moça de 28 anos, “(...) a esposa do meu pai é difícil, me dou bem com ela, mas é muito formal (....); apesar de morar no mesmo bairro, o relacionamento é bem distante. Não me sinto com liberdade de ir à casa dele na hora que for”(S. 21). Ou ainda, conforme depoimento de outra moça que, com muita raiva, afirmou: "[Gostaria] que ele não tivesse conhecido essa mulher, essa monstra. Que ele tivesse uma mulher normal, que não atrapalhasse a nossa relação, ou até que incentivasse" (S. 18). Cabe destacar que "aquela mulher" foi a expressão mais utilizada pelos filhos ao se referirem à companheira do pai.

A dificuldade em lidar com os companheiros dos pais também ficou evidente no relato de outra moça quando, ao se referir ao relacionamento que mantinha, no momento, com o pai e com a mãe, explicou: "Atualmente está numa fase ótima, porque meu pai e minha mãe estão solteiros” (S. 15).

Alguns, por uma questão de lealdade com o outro genitor, não se sentiam autorizados a gostar das madrastas ou dos padrastos, conforme explicou uma entrevistada de 23 anos: "Sou mais próxima da minha mãe, minha mãe é mais mãe, totalmente grudada, preocupada. Gosto até bastante da mulher do meu pai, mais do que deveria”(S. 17).

Como também observado por Wagner e Sarriera (1999), "É muito comum que se encontre nos filhos de famílias reconstituídas um conflito de lealdade com determinados elementos de sua família original, principalmente com os pais biológicos” (pp.16-17).

Os sujeitos entrevistados indicaram que o divórcio ou a separação dos pais é mais aceita quando não há grande mudança em termos do contato com os genitores. Muitos também demostraram ressentimentos e dificuldades para aceitar os vários filhos provenientes de diversas uniões do pai. "Meu pai casou com minha mãe, no segundo casamento teve o de 16 anos, e, com a terceira, o de nove; atualmente está com a quarta esposa. Média de um por jogo" (S. 22). "Meu pai teve uma filha que deve ter uns oito, nove, 10 anos, meia-irmã, né?” (S. 18).

Houve também os que não consideravam os outros filhos do pai como irmãos, usando termos como "coisa do meu pai", demonstrando dificuldade em reconhecê-los como membros de sua família.

Foi freqüente a explicação de que os homens, após a separação, constituíram outro relacionamento conjugal, passando a residir com a companheira ou nova esposa. Já com relação às mulheres, apesar de muitas mães da amostra terem namorados, foram poucos 
os casos em que passaram a residir com os novos companheiros, talvez, justamente, pela reação dos filhos. Como expressou um entrevistado: “Acho que ela não faria isso de trazer o namorado para morar aqui em casa" (S. 23). Ou, ainda, a moça que revelou: "Minha mãe acho que não vai casar não, tem 20 anos de relacionamento, mas moram em casas separadas. Ele morou com a gente por 3 meses, mas ela mandou ele voltar” (S. 25).

Evidente era o desconforto de alguns entrevistados em relação às constantes mudanças no rumo de suas vidas em decorrência dos novos relacionamentos dos pais, fato que, por vezes, significava uma adaptação a uma nova pessoa, mudança de residência e, em alguns casos, nova vivência de separação.

\section{Mudanças}

Ao serem questionados se gostariam de mudar algo no que abrange a separação dos pais, muitos foram os que responderam desejar que os pais se reconciliassem. "Ah, querer mudar a gente sempre quer, né? A gente quer que os pais fiquem juntos, né?”, disse o rapaz de 24 anos (S. 8). Já na visão de outra participante da pesquisa, apesar de não existir indicação de possibilidade de reconciliação entre os pais, "para quem acredita em Deus, nada é impossível” (S. 6).

Enquanto Wallerstein, Lewis e Blakeslee (2002) afirmam que "Os pais ficariam surpresos se constatassem que muitos filhos se apegam às esperanças de reconciliação até bem a entrada da adolescência” (p.132), poder-se-ia dizer, com surpresa, que semelhante esperança ou expectativa também foi constatada em muitos filhos adultos entrevistados.

Ainda na referência ao que gostariam de mudar, houve destaque nas repostas dos que lamentavam o distanciamento ou a ausência do pai por longos períodos de seu desenvolvimento, como o entrevistado que explicou o que, se pudesse, gostaria de mudar: "O fato de ter perdido contato com ele [o pai] ao longo desses anos”(S. 22). "Gostaria de ter uma proximidade maior com ele” (S. 21).

Já para outros, o essencial era, pelos menos, que os pais pudessem dialogar, se falar. Como exemplo, destaca-se o relato de uma entrevistada que gostaria que os pais tivessem um bom relacionamento, "principalmente em respeito aos filhos” (S. 3).

Rapizo et al (2001), ao realizarem grupos com adolescentes filhos de pais separados, destacaram que: “As mensagens deixadas para os pais, invariavelmente, ao final de cada grupo, são pedidos para que se entendam e não os coloquem no meio de sua guerra particular” (p.40).

\section{Conclusões}

Por meio da pesquisa desenvolvida, procurouse expor como os jovens adultos entrevistados retrataram suas vivências e sentimentos relacionados às situações decorrentes da separação dos pais, visando a contribuir com o mapeamento de alguns campos de dificuldade que, porventura, possam persistir após a separação conjugal. Como exposto ao longo do trabalho, não se teve a intenção de acalentar a idéia de que filhos de pais separados seriam problemáticos, ou ainda, de que a separação dos pais prejudicaria os filhos. Por intermédio dos depoimentos dos entrevistados, pôde-se compreender, todavia, que a separação conjugal não deve ser reduzida a uma situação corriqueira no contexto contemporâneo, à qual os filhos, simplesmente, se acostumam. Em contrapartida, foi observado que o rompimento da relação conjugal acarreta, comumente, um complexo processo de mudanças para os diversos componentes do núcleo familiar, sendo necessário estar atento para que os filhos 
não sejam fortemente atingidos por desdobramentos que possam trazer prejuízos ao seu bem-estar. Por certo, na atualidade, não há discriminação quanto ao divórcio, minimizando-se, portanto, as conseqüências sociais para os filhos, fato que pode não apresentar correspondência quando se examinam as vivências destes no contexto familiar.

Como descreveram os entrevistados, não é sempre que a separação é vista por eles como uma solução adequada aos desentendimentos entre os pais, até porque, como exposto anteriormente, muitos casais parecem discretos em suas brigas, evitando que os filhos presenciem fortes embates. Compreende-se, portanto, que, ao generalizar a interpretação de que o rompimento do par conjugal traria vantagens a pais e filhos, pode-se correr o risco de desconsiderar os últimos como sujeitos de direito que possuem sentimentos e necessidades que lhes são próprios. Entendese ainda que, com essa idéia, mais uma vez se estaria reunindo relacionamento conjugal e parentalidade, conceitos unificados por longos anos, quando predominava a visão de que, com a separação conjugal, o afastamento de um dos pais seria inevitável.
Na escuta dos que participaram da pesquisa, percebe-se que, para muitos, a separação não ocorreu apenas entre os pais, mas estendeuse ao relacionamento entre pais e filhos. Apontaram os entrevistados que muitas alterações em suas vidas decorrentes do divórcio dos pais não foram passageiras, sugerindo que a redução acentuada no relacionamento com um dos genitores, geralmente o pai, acarretou sentimentos e vivências de perda no relacionamento anos depois. Para muitos, o maior impacto foi essa desestabilização no relacionamento com o pai, quer seja por um período de tempo, quer seja ao longo de suas vidas. Aqueles que mantiveram um estreito contato com ambos, freqüentando as duas casas, mostraram menor desgaste emocional com o divórcio dos pais.

Compreende-se que reconhecer e identificar possibilidades de desdobramentos desagradáveis para os filhos após a separação dos pais torna-se o primeiro passo para o desenvolvimento de mecanismos de apoio às famílias contemporâneas, contribuindo-se para que sejam implementadas o que Giddens (1999) já denominou “estratégias políticas”. 
Leila Maria Torraca de Brito Professora-adjunta do Instituto de Psicologia da Universidade do Estado do Rio de Janeiro. Mestre e Doutora em Psicologia pela PUC/RJ.

Rua Barão de São Francisco, 120 apt. 801 Rio de Janeiro - RJ. CEP: 20560-032 E-mail: torraca@uerj.br

BARDIN, L. Análise de Conteúdo. Lisboa: Edições 70, 1979.

BRITO, L. Guarda Compartilhada: um Passaporte para a Convivência Familiar. In: Associação de Pais e Mães Separados (org.). Guarda Compartilhada: Aspectos Psicológicos e Jurídicos. Porto Alegre: Equilíbrio, 2005, pp.53-71.

FAUCHIER, A. e MARGOLIN, G. Affection and Conflict in Marital and Parent-Child Relationships. Journal of Marital and Family Therapy, v.30, n.2, pp.197-211, April 2004.

GIDDENS, A. A Terceira Via: Reflexões sobre o Impasse Político Atual e o Futuro da Social-democracia. Rio de Janeiro: Record, 1999.

GONZALEZ, M., CABARGA, P.L e VALVERDE, V.J. Percepciones Parentales en Ninõs de Famílias Separadas - una Nueva Versión del Síndrome de Estocolmo? Anuário de Psicología Jurídica, Madrid, pp.25-43, 1994.

HURSTEL, F. As Novas Fronteiras da Paternidade. Campinas: Papirus, 1999.

LE NOUVEL OBSERVATEUR. Quel modèle pour quelle vie? Papa, maman, la famille et moi..., 24-30, avril 2003.

MENDONÇA, M. Quando a Separação não É um Trauma. Época. São Paulo: Editora Globo, pp. 60-66, 24 jan. 2005.
POUSSIN, G. e LAMY, A. Custodia Compartida. Espanha: Espasa, 2005.

RAPIZO, R. et al. Continuando a Experiência: os Grupos de Mulheres e Filhos que Viveram o Divórcio. Nova Perspectiva Sistêmica, Rio de Janeiro: Instituto Noos, ano X, n.19, pp.36-42, ag. 2001.

SOUZA, R.M. Depois que Papai e Mamãe se Separaram: um Relato dos Filhos. Psicologia: Teoria e Pesquisa, v.16, n.3, pp.203-211, 2000.

WAGNER, A.; FALCKE, D. e MEZA, E. Crenças e Valores dos Adolescentes acerca de Família, Casamento, Separação e Projetos de Vida. Psicologia: Reflexão e Crítica, Porto Alegre, v. 10, n.1, pp.155-167, 1997.

WAGNER, A e SARRIERA, J. C. Características do Relacionamento dos Adolescentes em Famílias Originais e Reconstituídas. In: FéresCarneiro, T. (org.). Casal e Família: entre a Tradição e a Transformação. Rio de Janeiro: Nau, 1999, pp.15-30.

WALLERSTEIN, J. e KELLY, J. Sobrevivendo à Separação: como Pais e Filhos Lidam com o Divórcio. Porto Alegre : Artmed, 1998.

WALLERSTEIN,J.; LEWIS,J.eBLAKESLEE,S. Filhos do Divórcio. São Paulo: Edições Loyola, 2002. 